\title{
Brand Positioning Map: A Strategy Tool for Trademark Design
}

\author{
Rain Chen ${ }^{1} \&$ Ming-Hong Wang ${ }^{2}$ \\ ${ }^{1}$ Department of Creative Product Design, Southern Taiwan University of Science and Technology, Taiwan, R.O.C. \\ ${ }^{2}$ Graduate School of Digital Content and Applied Design, Southern Taiwan University of Science and Technology, \\ Taiwan, R.O.C. \\ Correspondence: Dr. Rain Chen, No. 1, Nan-Tai Street, Yongkang Dist., Tainan City 710, Taiwan R.O.C.. Tel: \\ 886-6-253-3131. E-mail: ocean@mail.stust.edu.tw
}

Received: December 26, 2014

Accepted: January 13, 2015

Online Published: January 26, 2015

doi:10.5430/jms.v6n1p36

URL: http://dx.doi.org/10.5430/jms.v6n1p36

\begin{abstract}
The study used multidimensional scaling to build designer and consumer Brand Position Map, BPM. The research objectives are as follows: (1) Using trademark samples to build BPM, (2) comparing substantive differences between BPM built by designers and by consumers, (3) presenting a well-known trademark infringement case and using BPM to simulate a design strategy for the new trademark. The study chose 29 trademark samples of 29 boutique brands and requested 26 designers and 56 consumers to build the BPM. The investigators analyzed a classic trademark infringement case, HERMES vs. BNANE, and simulated a "New BANANE Trademark" design strategy. The investigators have found that the BPM built by designers have the trademark samples more concentrated, which suggests that designers' judgment on trademark samples are more consistent. As for consumers, their BPM has the trademark samples more dispersed, suggesting that their judgment on trademark samples is less consistent. Together, it means that experts and the general public use different standard for judging trademarks. In the HERMES vs. BANAE trademark case, BPM enables the investigators to clearly define the infringement scope of the trademark. BPM can also be used to simulate a design strategy for a new trademark. BPM provides a good brand positioning concept assisting the middle and high level company managers to implement brand positioning. BPM covers a wide range of aspects, including using BPM: (1) as a brand positioning analysis tool in the industry, (2) for design around of trademark design, and (3) for assessing the infringement scope of trademarks. Future researchers can also more thoroughly examine the application of BPM in different industries. BPM is a strategy tool for brand design. Using corporate brand positioning strategy is an approach for dealing with competitions among enterprises. BPM is a very effective ad comprehensive strategic tool for enterprises interested in more definite brand positioning.
\end{abstract}

Keywords: brand position, trademark design, strategy tool

\section{Introduction}

A trademark is like a symbol, a sign, a design or a label. For consumers, trademarks represent product and service commitment. Trademarks also provide consumers with a clear corporate picture and boost consumers' purchase intention (Park et al., 1986). Brands are the expansion of trademarks. An example of a trademark expanding into a brand is the formation of a stereotypical image in consumers for a trademark that has been extensively applied. In this case, the trademark can be viewed as being expanded into a brand.

Brands can be viewed as a name, a logo, or an external symbol. It represents the inner spirit of an enterprise. Brand design has a significant impact on the overall development of an enterprise (George et al., 2012), while trademarks are the foundation where an enterprise builds its brand. Both the brand and the trademark have to be carefully planned and designed in order to be easily differentiated in the competitive market (Ries and Ries, 1998). Making a good use of the brand positioning strategy enables the company to boost its economic benefits and have its strengths highlighted (Chen and Cheng, 2012).

Brand development relies on a well-defined market position for consumers to easily associate a brand with its products or services. The position of a brand is formed based on consumers' viewpoints of the brand, which can be related to a comparison of functions between brands or affected by the attractiveness of a brand (Upshaw, 1995). Brands have to be effectively managed, and brand value is accumulated constantly, and eventually, it will become part of the corporate asset (Wood, 2000). 
Brand positioning takes place at the initial stage of trademark design. In the process, the core value of the enterprise is gradually converted into visual elements. The enterprise then decomposes, combines, and simplifies these new visual elements, and after a series of complicated trademark design steps, a visual trademark representing the image of the enterprise is generated. The importance of positioning is to enable the enterprise to recognize consumers' expectation of the image of the products (DiMingo, 1988). Positioning is a strategic tool, and it is a strategy too called positioning strategy (Maggard, 1976).

Trademark identifiability plays a critical role in brand positioning implementation. The quality of trademark identifiability is determined by consumers' direct viewpoints. When taking the Trademark Act into consideration, a more crucial task here is to ensure that the trademark will not confuse or mislead consumers. According to the TIPO, the examination standards are published and eight judging factors are brought up (Chen and Cheng, 2013) as (1) level strength of distinctiveness of the trademark(s), (2) whether the trademarks are similar and if yes, the extent of similarity between them, (3) whether the goods/services are similar and if yes, the extent of similarity between them, (4) status of the diversified operation of the prior right holder, (5) circumstances of actual confusion, (6) the extent to which relevant consumers are familiar with the trademarks concerned, (7) whether the applicant of the trademark at issue in question has filed such application in good faith, and (8) other factors that may cause confusion.

The former studies focus on "Corporate Identity". They are lack to discussion for brand's design strategy. This study proposed to be used strategy tool for brand design. This tool assists designers to carry out design around and helps the judge to make infringement judgment.

In this study, the investigators took the perspective of the Trademark Act to build a brand positioning map (BPM). The research objectives are as follows: (1) Using trademark samples to build BPM, (2) comparing substantive differences between BPM built by designers and by consumers, (3) presenting a well-known trademark infringement case and using BPM to simulate a design strategy for the new trademark.

Sometimes, those similar or of a same type of products provided by similar industries or the same industry may confuse or mislead consumers. Therefore, the investigators chose brands of a same industry and selling similar products as the research samples.

\section{Method}

The study used multidimensional scaling to build designer and consumer BPM. The investigators then explored a well-known trademark infringement case (HERMES vs. BANANE). Lastly, the investigators introduced the well-known trademark infringement case and used BPM to simulate a design strategy for creating a new trademark.

\subsection{Subjects}

There are a total of 82 subjects, and among them, 26 are designers. The average years practicing design of the designers are more than three years. There are 56 consumers, and they are general and non-specific.

\subsection{Samples}

Among many industries, the boutique industry relies heavily on their brands for brining substantial profits. From the trademark database, the investigators selected registered trademarks from the boutique industry as the research samples. A total of 29 trademark samples were selected and coded (R1 to R29). The registration data of trademark samples are presented in Table 1.

Table 1. Registration data of trademark samples

\begin{tabular}{lllll}
\hline $\begin{array}{l}\text { Number of } \\
\text { samples }\end{array}$ & $\begin{array}{l}\text { Trademark } \\
\text { name }\end{array}$ & Country & $\begin{array}{l}\text { Approval } \\
\text { year }\end{array}$ & Trademark owner \\
\hline R1 & HERMES & France & 1978 & HERMES INTERNATIONAL \\
\hline R2 & Bally & United States of America & 1989 & $\begin{array}{l}\text { CAESARS LICENSE COMPANY, } \\
\text { LLC }\end{array}$ \\
\hline R3 & BURBERRY & $\begin{array}{l}\text { United Kingdom of Great } \\
\text { Britain and Northern } \\
\text { Ireland }\end{array}$ & 1974 & BURBERRY LIMITED \\
\hline R4 & BVLGARI & Italy & 1980 & BULGARI S.P.A. \\
\hline R5 & CHANEL & Switzerland & 1990 & CHANEL SARL \\
\hline
\end{tabular}




R6 Calvin Klein $\quad$ United States of America $1993 \quad \begin{aligned} & \text { CALVIN KLEIN TRADEMARK } \\ & \text { TRUST }\end{aligned}$

R7 COACH $\quad$ United States of America $2012 \quad$ COACH, INC.

\begin{tabular}{|c|c|c|c|c|}
\hline $\mathrm{R} 8$ & $D \& G$ & Italy & 2000 & $\begin{array}{l}\text { DOLCE \& GABBANA } \\
\text { TRADEMARKS S.R.L. }\end{array}$ \\
\hline R9 & DIESEL & Italy & 1992 & DIESEL S.P.A. \\
\hline R10 & DIESEL & Italy & 1992 & DIESEL S.P.A. \\
\hline R11 & FENDI & Italy & 1998 & FENDI ADELE S.R.L. \\
\hline R12 & GUCCI & Italy & 1977 & GUCCIO GUCCI S.P.A. \\
\hline R13 & GUESS & United States of America & 1983 & GUESS INC. \\
\hline R14 & JIL SANDER & Germany & 1985 & JIL SANDER AG \\
\hline R15 & LACOSTE & France & 1983 & LACOSTE S.A. \\
\hline R16 & LOEWE & Spain & 1988 & LOEWE S.A. \\
\hline $\mathrm{R} 17$ & $\begin{array}{l}\text { LOUIS } \\
\text { VUITTON }\end{array}$ & France & 1987 & LOUIS VUITTON MALLETIER \\
\hline R18 & MONT BLANC & Germany & 2001 & MONTBLANC-SIMPLO GMBH \\
\hline R19 & MOSCHION & Italy & 2007 & MOSCHION CHEAPANDCHIC \\
\hline $\mathrm{R} 20$ & $\begin{array}{l}\text { RALPH } \\
\text { LAUREN }\end{array}$ & United States of America & 1980 & $\begin{array}{l}\text { THE POLO/LAUREN COMPANY, } \\
\text { L.P. }\end{array}$ \\
\hline R21 & PRADA & Luxembourg & 2010 & PRADA S.A. \\
\hline $\mathrm{R} 22$ & Pringle & $\begin{array}{l}\text { United Kingdom of Great } \\
\text { Britain and Northern } \\
\text { Ireland }\end{array}$ & 1997 & $\begin{array}{l}\text { PRINGLE OF SCOTLAND } \\
\text { LIMITED }\end{array}$ \\
\hline $\mathrm{R} 23$ & $\begin{array}{l}\text { Salvatore } \\
\text { Ferragamo }\end{array}$ & Italy & 1994 & SALVATORE FERRAGAMO S.P.A. \\
\hline R24 & TRUSSARDI & Italy & 1977 & TRUSSARDI S.P.A. \\
\hline $\mathrm{R} 25$ & VERSACE & Italy & 1991 & GIANNI VERSACE S.P.A. \\
\hline $\mathrm{R} 26$ & $\begin{array}{l}\text { Vivienne } \\
\text { Westwood }\end{array}$ & Luxembourg & 1994 & LATIMO S.A. \\
\hline $\mathrm{R} 27$ & ZARA & Spain & 2007 & $\begin{array}{l}\text { INDUSTRIA DE DISENO TEXTIL, } \\
\text { S.A. (INDITEX, S.A.) }\end{array}$ \\
\hline R28 & agnes $b$. & France & 2005 & B. FOREVER \\
\hline $\mathrm{R} 29$ & SWAROVSKI & Republic of China & 1994 & $\begin{array}{l}\text { SWAROVSKI } \\
\text { AKTIENGESELLSCHAFT }\end{array}$ \\
\hline
\end{tabular}

For trademark samples, the trademark image is presented on cards coded (R1 to R29). There are a total of 29 trademark pictures chosen from the boutique industry. See Figure 1. 


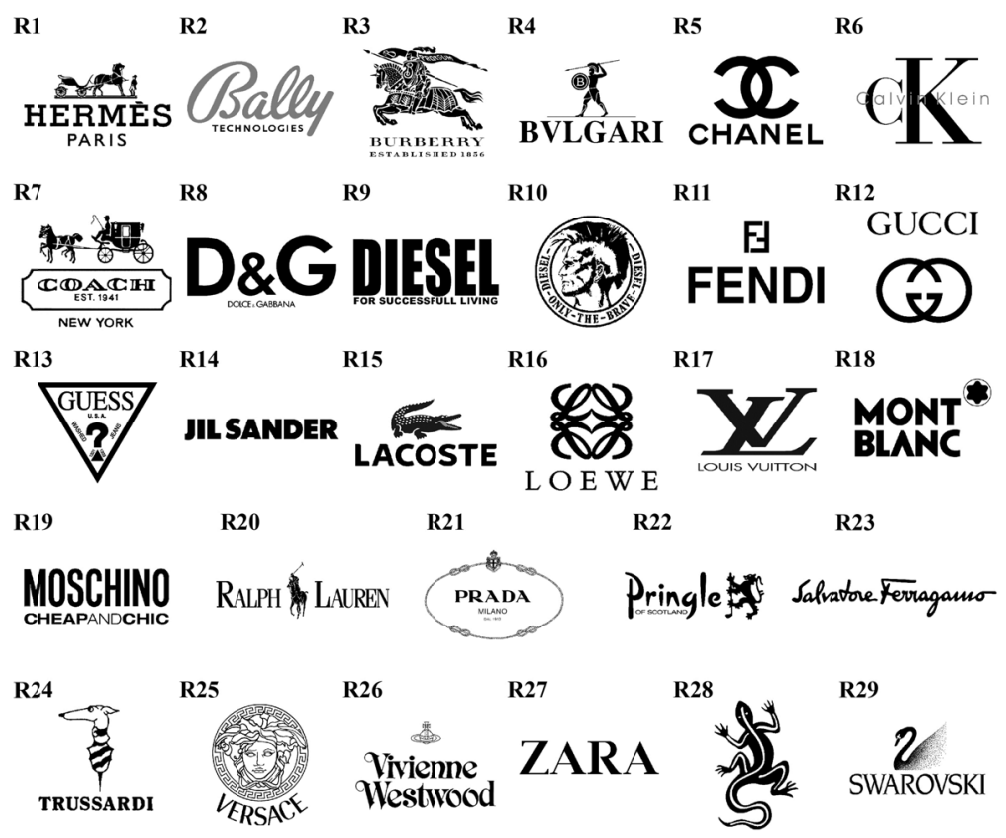

Figure 1. Trademark picture cards and their codes

\subsection{Experiment Planning}

The study comprises two parts. In part 1, the investigators analyzed BPM differences between designers and consumers. In Part 2, the investigators analyzed the distance relationship of the trademark case and simulated a design strategy for creating a new trademark.

The size of picture cards used for showing the image of trademark samples (R1 to R29) is $75 \mathrm{~mm} \times 75 \mathrm{~mm}$. The investigators requested the subjects (including designers and consumers) to judge the level of similarity of these trademark samples; they were asked to group the picture cards into at least six groups but no more than nine groups. Figure 2 shows the grouping of the trademark samples.

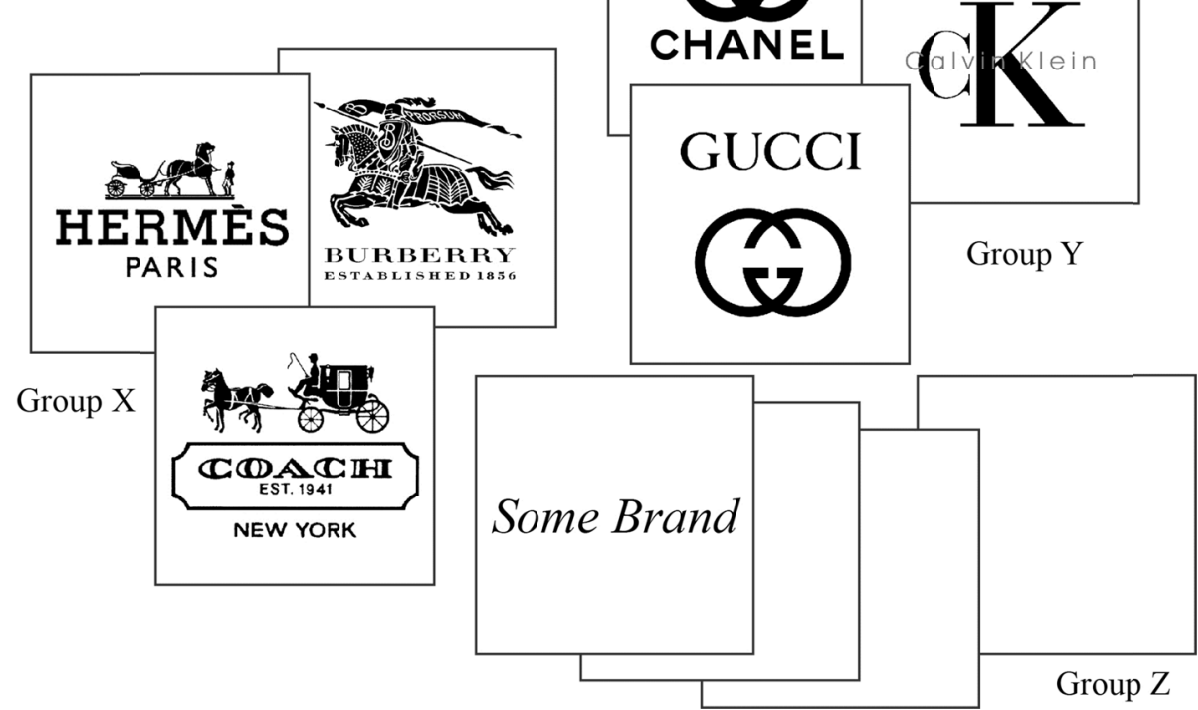

Figure 2. Grouping of trademark sample picture cards 
To ensure that the subjects are not affected by the color of brands, the color of trademark samples was removed. In addition, to help consumers perform identification and differentiation among the trademarks more easily, the resolution of the trademark sample was set to $800 \times 600$ pixel or above.

\subsection{Tool}

The study used multidimensional scaling to form BPM, which shows the overall brand layout of the boutique industry. It is found from the literature review that many academics when discussing issues related to position strategies, they would use this approach to analyze. Multidimensional scaling clearly demonstrates the distance between brands, which is a useful information for trademark modification and design.

\subsection{Case Analysis}

The objective of the study is to explore brand positioning and to simulate a trademark design strategy. The investigators chose a classic trademark infringement case, HERMES vs. BANANE, for the case analysis.

HERMES Company (HEMRES INTERNATIONAL) was founded in Paris in 1837 (HERMES, 2014). HERMES is the world's leading boutique brand and has its branches across the world. Aside from leather-based products, HERMES also sells clothing, accessories, silk, fabrics, perfumes and others. HERMES entered into the Taiwan market in 1980, and the Birkin bag is coveted by consumers in Taiwan.

Between December 2004 and June 2005 BANANA INTERNATIONAL of Taiwan imported and sold four types of HERMES counterfeiting bags. The plaintiff (HEMRES INTERNATIONAL) claimed that the counterfeiting case had caused HERMES a loss of nearly 1.5 billion NTD. The court ruled that the defendant (BANANA INTERNATIONAL) should pay the plaintiff (HEMRES INTERNATIONAL) two hundred million five thousand six hundred and twenty-five NTD (Intellectual Property Court Ruling, 2009). This is a very classic trademark infringement case and therefore, the study will pay attention on the trademark design and positioning of HERMES and BANANE.

\section{Result}

Data related to the subjects (including number of subjects; number of male and female; percentages; pressure coefficient; and RSQ) are summarized in Table 2. There are 82 subjects: 26 designers and 56 consumers.

Table 2. Subject profiles

\begin{tabular}{|c|c|c|c|c|c|}
\hline Subjects & $\begin{array}{c}\text { Number of } \\
\text { subjects }\end{array}$ & $\begin{array}{l}\text { Number of male } \\
\text { and female }\end{array}$ & Percentages & $\begin{array}{c}\text { Pressure } \\
\text { coefficient }\end{array}$ & RSQ \\
\hline \multirow{3}{*}{ Designers } & \multirow{3}{*}{26} & Male: 12 & $46 \%$ & \multirow{3}{*}{0.92} & \multirow{3}{*}{0.02} \\
\hline & & & & & \\
\hline & & Female: 14 & $54 \%$ & & \\
\hline \multirow{3}{*}{ Consumers } & \multirow{3}{*}{56} & Male: 18 & $32 \%$ & \multirow{3}{*}{0.84} & \multirow{3}{*}{0.02} \\
\hline & & 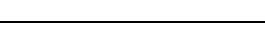 & 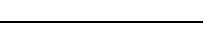 & & \\
\hline & & Female: 38 & $68 \%$ & & \\
\hline
\end{tabular}

\subsection{Brand Position}

Figure 3 shows designers' judgment on the trademark samples. The result suggests that in the boutique sector, while most trademarks have a good brand positioning, some trademarks are pretty similar (e.g., R22 and R24, R16, R21 and R26, R11 and R13, and R10 and R27). The BPM built by the designers have the trademark samples more concentrated, suggesting that the designers' judgment on trademark samples is more consistent. 


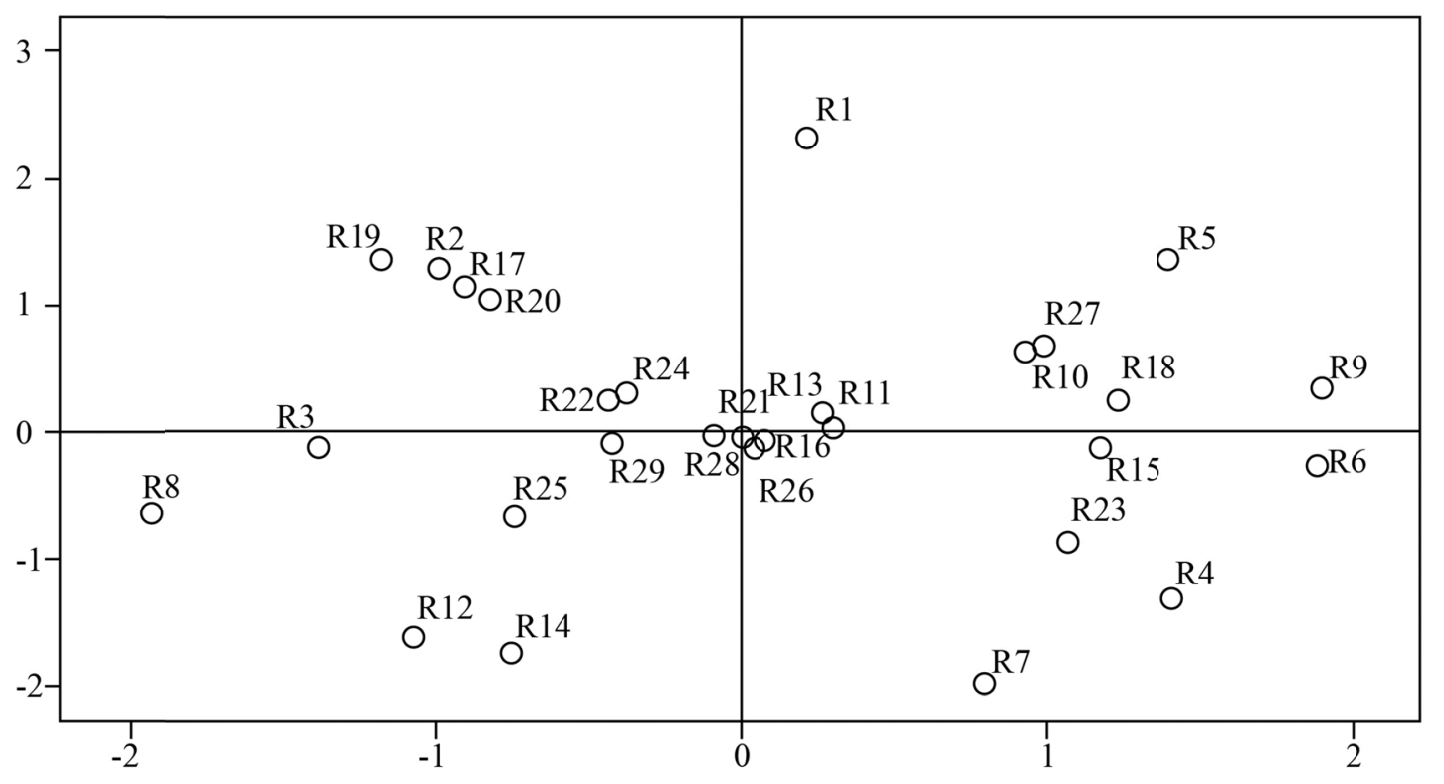

Figure 3. Brand positioning map constructed by designers

Figure 4 shows consumers judgment on the trademark samples. The result suggests that in the boutique sector, while most trademarks have a good brand positioning, some trademarks are pretty similar (e.g., R23 and R24). The BPM built by the consumers have the trademark samples more dispersed, suggesting that the consumers judgment on trademark samples is more less consistent.

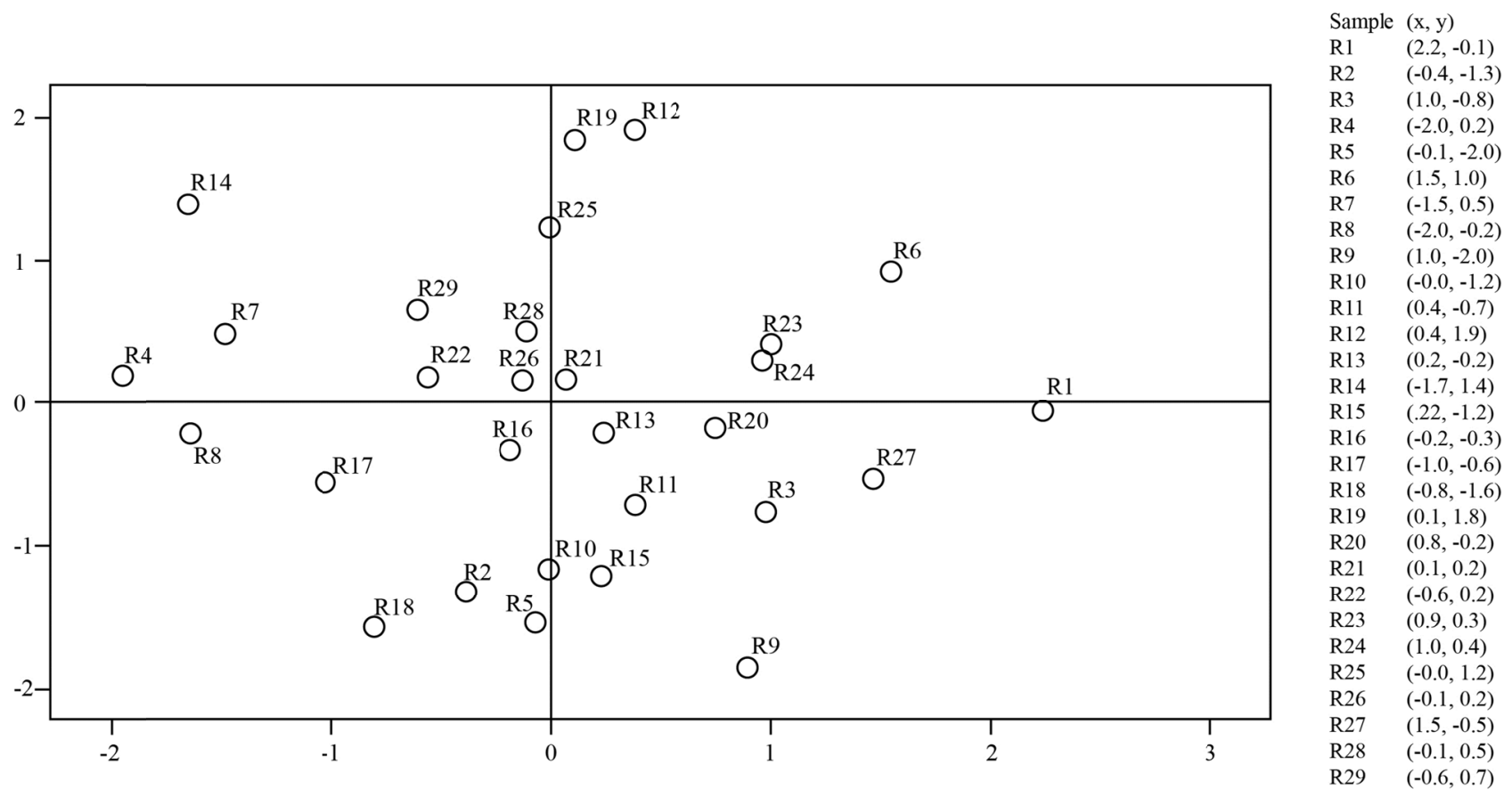

Figure 4. Brand positioning map constructed by consumers

Overall, designers are more capable of clearly defining the trademark samples. Designers' perception of a trademark is based on the design (the picture) of the trademark, while consumers' perception of a trademark is based on their overall impression of the brand. 


\subsection{Infringement Case}

Between 2004 and 2005, HEMRES INTERNATIONAL detected that the trademark of BANANA INTERNATIONAL infringing HERMES' trademark and filed a lawsuit against BANANA INTERNATIONAL. The disputed trademark design elements are the word "HERMES" and the image of a horse and a carriage, but BANANA INTERNATIONAL argued that the design elements of their trademark are the words "BANANE" and "TAIPEI", and the images of a banana, a horse, a carriage and a person. Because both parties' trademark images are applied onto their boutique products, especially bags (qualifying the criterion of same sector and same product). At the end, the Intellectual Property Rights Court quoted the Trademark Act and ruled HERMES winning the lawsuit because the brand design image of BANANA INTERNATIONAL confuses consumers. The trademark of HERMES (the plaintiff) and of BANANE (the defendant) are shown in Figure 5.

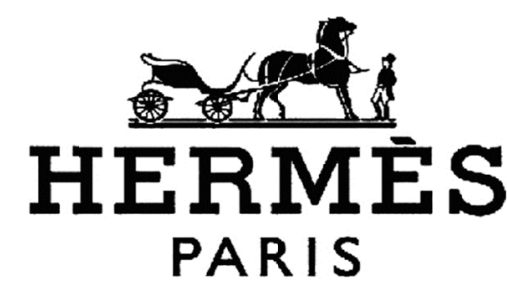

HERMES's brand

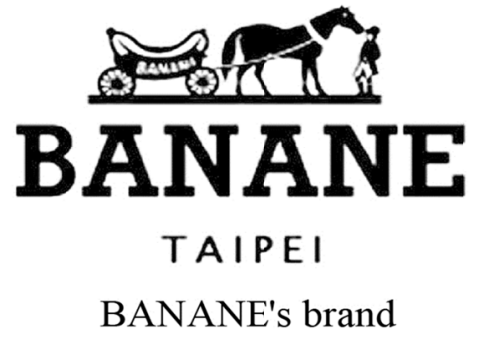

Figure 5. Trademarks of the defendant and of the plaintiff

\subsection{Strategy of Brand Design}

In the aforementioned case, the ruling of BANANE trademark infringing the HERMES trademark is confirmed. The objective of the study is to explore the application of BPM by having designers adopting BPM to ensure that existed trademarks with similarity are taken into consideration when designing a new trademark so the new trademark will not infringe the scope of the right of other trademarks.

The investigators put themselves in the place of the defendant (BANANE trademark), and since the court ruled that the BANANE trademark had infringed the HERMES trademark, the image of these two trademarks may be confusing and misleading. The next step that BANANA INTERNATIONAL should take is to modify the BANANE trademark to avoid losing the original consumer groups. Moreover, the investigators made the assumption that BANANA INTERNATIONAL wants to keep the coach and the words below the coach in the BANANE trademark.

To provide the designers with a clear hint about the direction for designing the new trademark and to take the brand positioning angle for re-planning a strategy for the BANANE trademark, the investigators used the HERMES trademark as the radius to define the protection range of the HERMES trademark. The new trademark design case for BANANE is called "New BANANE Trademark, NBT". Figure 6 shows the diagram of NBT positioning strategy.

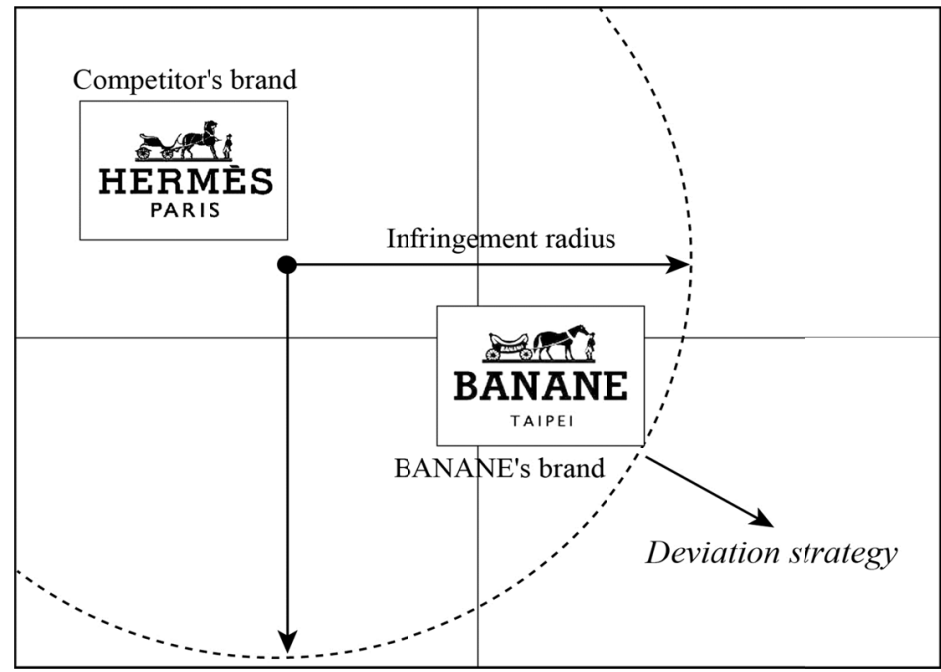

Figure 6. Positioning strategy of NBT 


\subsection{New Trademark Design- NBT}

It can be found from Figure 6 that the investigators used a deviation competing brand as the brand design strategy and requested designers to follow the rule to redesign the trademark of BANANE. The new trademark has a streamlined contour and the font chosen for the new trademark is distinctively different from the one used by HERMES. The NBT design is shown in Figure 7.

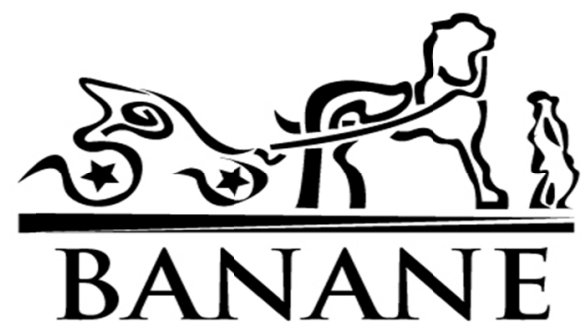

Figure 7. New trademark design- NBT

The investigators then used multidimensional scaling again to simulate R1-R29, BANANE, and NBT (a total of 31 trademark pictures). The BPM that includes NBT is shown in Figure 8.

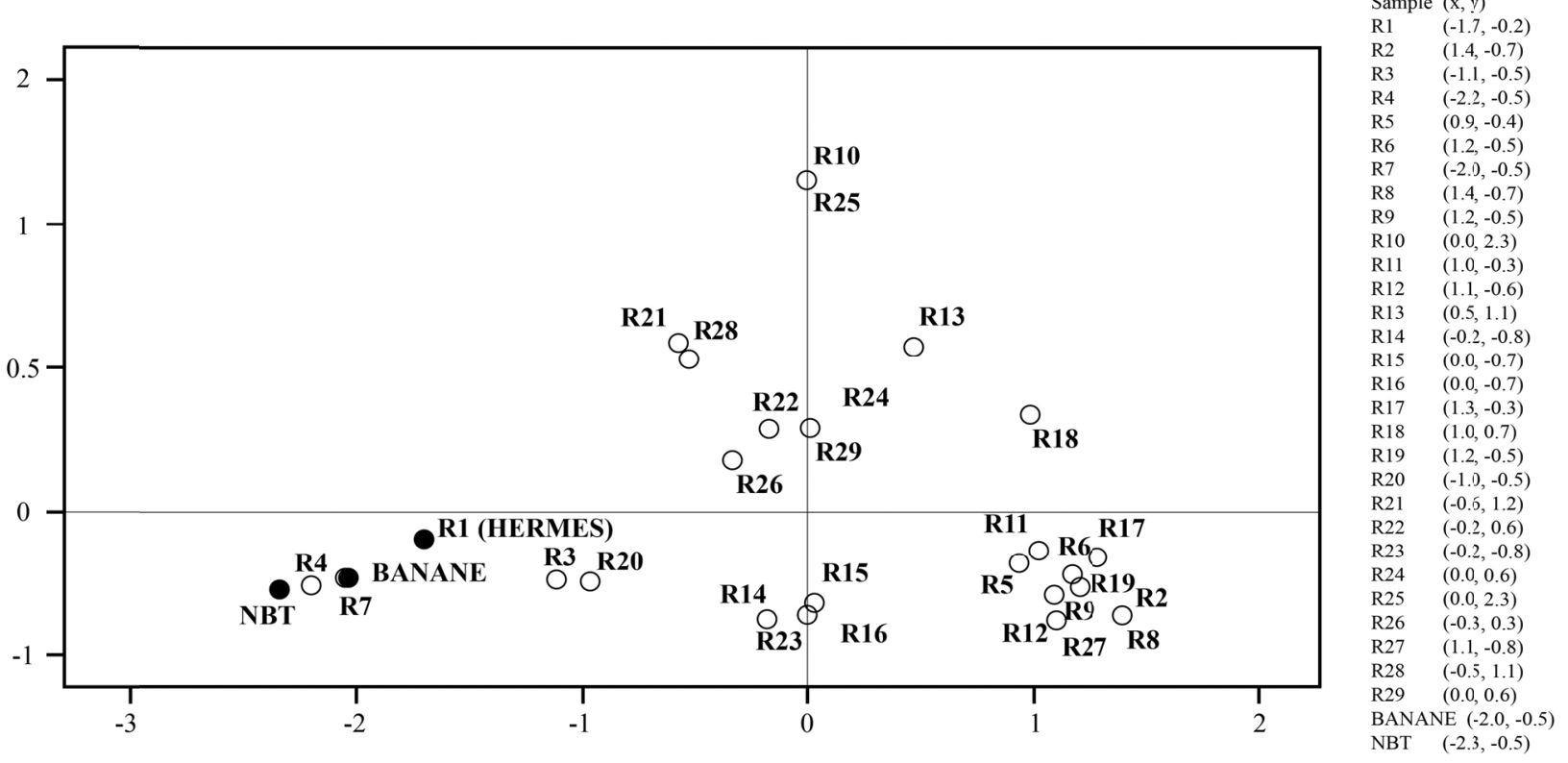

Figure 8. The BPM with NBT

It can be found from Figure 8 that designers can use BPM for reference in trademark design modification. The design direction of NBT is not only to be deviated from the target (HERMES) but also to have a certain level of distinctiveness from other registered boutique brands.

If the distance between the target (HERMES) and BANANE is defined as the infringement distance, then one can intentional keep NBT away from the area with the distance as the radius to ensure that NBT will not infringe the HERMES trademark again. From the aspect of corporate brand positioning, this strategy tool is effective in providing brand design with a definite direction.

\section{Discussion and Conclusion}

The study chose 29 trademark samples of 29 boutique brands and requested 26 designers and 56 consumers to build the BPM. Next, the investigators analyzed a classic trademark infringement case, HERMES vs. BNANE, and 
simulated a "New BANANE Trademark, NBT" design strategy.

The investigators have found that the BPM built by designers have the trademark samples more concentrated, which suggests that designers' judgment on trademark samples are more consistent. As for consumers, their BPM has the trademark samples more dispersed, suggesting that their judgment on trademark samples is less consistent. Together, it means that experts and the general public use different standard for judging trademarks. Because in a trademark infringement trial, whether the accused trademark is confusing for consumers and viewpoints from experts will be taken into consideration, it is recommended for subsequent studies to track differences between the two and verify whose (experts' or the general public's) judgment is closer to the viewpoint of the judge.

In the HERMES vs. BANAE trademark case, BPM enables the investigators to clearly define the infringement scope of the trademark. BPM can also be used to simulate a design strategy for a new trademark. BPM provides a good brand positioning concept assisting the middle and high level company managers to implement brand positioning.

The BPM proposed by the study is to be used as a strategy tool for brand design. With this strategy tool, relating participants (including designers or even the judge) can make more objective professional judgment. This tool assists designers to carry out design around and helps the judge to make infringement judgment.

The study used multidimensional scaling to form BPM. As the dimension increases, the acquired data become more accurate. The value of this study lies in the formation of visualized BPM; a two dimensional BPM is better for judgment making. Nonetheless, is also has some shortcomings. For example, R4 and NBT in Figure 8 are not similar but their distance is short. It is because the two-dimension approach is associated with the problem of afterpicture. How to use the pressure coefficient and RSQ to determine the afterpicture is an issue requiring further exploration.

BPM covers a wide range of aspects, including using BPM: (1) as a brand positioning analysis tool in the industry, (2) for design around of trademark design, and (3) for assessing the infringement scope of trademarks. Future researchers can also more thoroughly examine the application of BPM in different industries.

BPM is a strategy tool for brand design. Using corporate brand positioning strategy is an approach for dealing with competitions among enterprises. BPM is a very effective ad comprehensive strategic tool for enterprises interested in more definite brand positioning.

\section{Acknowledgement}

This work was partially supported by the Ministry of Science and Technology (MOST), Taiwan, under the Grant No. NSC 102-2221-E-218-013-MY2.

\section{References}

Chen, R., \& Cheng, I. T. (2012). The Image Confusion in Trademark Map. Advances in Information Sciences and Service Sciences, 4(20), 27-34. http://dx.doi.org/10.4156/aiss.vol4.issue20.4

Chen, R., \& Cheng, I. T. (2013). Studying Factors Causing Wordmark Confusions to Improve Brand Identity. International Journal of Information and Management Sciences, 24(3), 265-277.

DiMingo, E. (1988). The Fine Art of Positioning. The Journal of Business Strategy, 9(2), 34-39. http://dx.doi.org/10.1108/eb039211

George, A., Victor, A., \& Pascuc, N. E. (2012). Logo Design and the Corporate Identity. Procedia-Social and Behavioral Sciences, 51, 650-654. http://dx.doi.org/10.1016/j.sbspro.2012.08.218

HERMES. (2014). Retrieved December 26, 2014, from http://www.hermes.com/index_default.html; $\mathrm{http} / / / \mathrm{www}$. cnyes.com/usastock/statutory.aspx? code $=$ hesay\&qm_page $=60754$

IPRC. (2009). Referee File of Intellectual Property Rights Court. No. 97-1.

Maggard, J. P. (1976). Positioning Revisited. The Journal of Marketing, 40(1), 63-66. http://dx.doi.org/10.2307/1250678

Park, C. W., Jaworski, B. J., \& Maclnnis, D. J. (1986). Strategic Brand Concept-Image Management. Journal of Marketing, 50(4), 135-145. http://dx.doi.org/10.2307/1251291

Ries, A., \& Ries, L. (1998). The 22 Immutable Laws Of Branding: How to build a product or service into a world-class brand. HarperCollins Publishers.

Upshaw, L. B. (1995). Building Brand Identity: A Strategy for Success in Hostile Marketplace. TTV Cultural Enterprise Ltd.

Wood, L. (2000). Brands and Brand Equity: Definition and Management. Management Decision, 38(9), 662-669. http://dx.doi.org/10.1108/00251740010379100 